\section{NK372135s, NOVEL ANTIFUNGAL AGENTS PRODUCED BY Neosartoria fischeri}

\section{Tomio Morino, Masakazu Nishimoto, Noriko Itou and TAKaAkI Nishikiori \\ Research Laboratories, Pharmaceutical Group, Nippon Kayaku Co. Ltd., \\ 31-12, Shimo 3-chome Kita-ku, Tokyo 115, Japan}

(Received for publication August 2, 1994)

In the course of screening program for antifungal agents, novel three congenial compounds were isolated from the cultured broth of fungus, Neosartoria fischeri var. glabra IFO9857. The congeners had a basal structure, which was di-hydrogenated form of xanthocillin ${ }^{1)}$ group and showed strong growth inhibition activity against Candida albicans in vitro. In this paper we report the isolation, structural elucidation and preliminary biological activity of the compounds, named NK372135A, B and C.

The antifungal activity was monitored by usual agar plate method with Candida albicans TIMM0144 provided by Research Center for Mycology, Teikyo Univ. The compounds were produced by rotary shaking culture of the strain in the medium containing glucose $2 \%$, lactose $1 \%$, sucrose $1 \%$, glycerol 1\%, Prorich (Ajinomoto Co. Ltd.) 2\%, peptone $0.8 \%, \mathrm{NaNO}_{3} 0.2 \%$ and $\mathrm{MgSO}_{4} 0.1 \%$. The maximum productivity was attained on 5 days cultivation at $27^{\circ} \mathrm{C}$. Mycelia were collected from 20 liters cultured broth by filtration, suspended in 10 liters of $\mathrm{MeOH}$ and removed by filtration. The resultant filtrate was applied on carbon column $(0.5$ liter) and elution was done with $\mathrm{Me}_{2} \mathrm{CO}$ after washing with $\mathrm{MeOH}$. The active eluate was evaporated to dryness under reduced pressure to give a brownish residue $(5 \mathrm{~g})$. This residue was applied on silica gel column and developed with the mixture of $\mathrm{CHCl}_{3}-\mathrm{MeOH}(100: 1,100: 2$ and $2: 1$, stepwisely). By this chromatography three active fractions were obtained and a putative compound in each fraction was named NK372135A, B and C in the order of the eluation. After evaporation of each fraction, the residue was subjected to Sephadex LH-20 column, developed with $\mathrm{MeOH}$. The NK372135A, $B$ and $C$ thus obtained were concentrated to give $88 \mathrm{mg}$ of $\mathrm{A}, 500 \mathrm{mg}$ of $\mathrm{B}$ and $108 \mathrm{mg}$ of $\mathrm{C}$ in the form of yellowish powder.

NK372135A, B and $\mathrm{C}$ were soluble in $\mathrm{CHCl}_{3}$ and $\mathrm{MeOH}$ but insoluble in $\mathrm{H}_{2} \mathrm{O}$, and gave positive color reaction with phosphomolybdic acid sulfuric acid and iodine reagents. On silica gel TLC( Merck Art. No. 5715) developed with $\mathrm{CHCl}_{3}-\mathrm{MeOH}(100: 2)$, $\mathrm{NK} 372135 \mathrm{~A}, \mathrm{~B}$ and $\mathrm{C}$ gave a single spot at $\mathrm{Rf}=0.66$, 0.40 and 0.13 , respectively. Physico-chemical properties were as follows. A: HRFAB-MS $m / z$ Found: $318.1364\left(\mathrm{M}+, \mathrm{C}_{20} \mathrm{H}_{18} \mathrm{O}_{2} \mathrm{~N}_{2}\right.$, Calcd: 318.1369$)$; $\mathrm{UV} \lambda_{\max }^{\mathrm{McOH}} \mathrm{nm} 225,297$; IR $(\mathrm{KBr}) \mathrm{cm}^{-1} 3438,2137$, 2103, 1605, 1514, 1252, B: HRFAB-MS $m / z$ Found: $348.1479\left(\mathrm{M}+, \mathrm{C}_{21} \mathrm{H}_{20} \mathrm{O}_{3} \mathrm{~N}_{2}\right.$, Calcd: 348.1473); $[\alpha]_{\mathrm{D}}^{20}+188.7(c 1.0, \mathrm{MeOH}) ; \mathrm{UV} \lambda_{\max }^{\mathrm{MeOH}} \mathrm{nm} 226$, 290, 317; IR (KBr) cm $\mathrm{cm}^{-1} 3438,2137,2102,1515$, 1273, 1249, C: FD-MS $m / z 334(\mathrm{M}+)$; UV $\lambda_{\max }^{\mathrm{MeOH}}$ $\mathrm{nm} 224,285,290,318$; IR (KBr) cm ${ }^{-1} 3412,2138$, 2102, 1603, 1583, 1513, 1279, 1248.

The ${ }^{1} \mathrm{H}$ and ${ }^{13} \mathrm{C}$ NMR spectrometric data of NK372135A was shown in Table 1, with that of xanthocillin X dimethylether (XDE) ${ }^{2)}$. XDE had a symmetrical structure (Fig. 1) and its assignment of NMR data was shown in Table 1. In comparison with XDE there appeared remarkablly different signals in the spectrum of NK372135A, i.e. $\delta_{\mathrm{H}} 4.76$ $(\mathrm{t}, 7.3), 3.13$ (dd, 7.3, 13.6), 3.19 (dd 7.3, 13.6) and $\delta_{\mathrm{C}} 61.14(\mathrm{~d}), 40.33(\mathrm{t})$ (Table 1). In COSY NMR analysis, strong signals were detected at $\delta_{\mathrm{H}} 3.13$, 3.19 vs. $\delta_{\mathrm{H}} 4.76$, at $\delta_{\mathrm{H}} 4.76$ vs. $\delta_{\mathrm{C}} 61.14$ and at $\delta_{\mathrm{H}} 3.13,3.19$ vs. $\delta_{\mathrm{C}} 40.33$. These data gave the partial structure that one of the double bond $\left(\mathrm{C}_{2}-\mathrm{C}_{3}\right)$ of XDE was hydrogenated (Fig. 1) and the signals were assigned as shown in Table 1 . This idea was

Fig. 1. The structures of xanthocillin (left) and NK372135 derivatives (right)
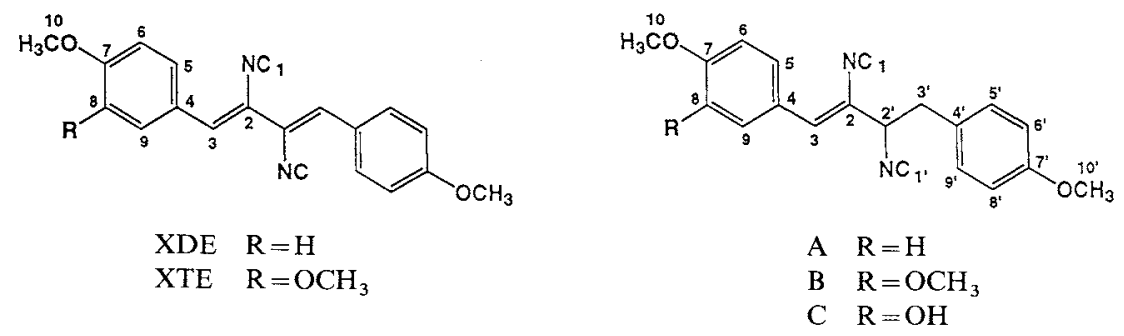
Table 1. ${ }^{1} \mathrm{H}$ and ${ }^{13} \mathrm{C}-\mathrm{NMR}$ spectrometric data of xanthocillin $\mathrm{X}$ dimethylether (XDE) and NK372135A $\mathrm{A}^{\mathrm{a}}$.

\begin{tabular}{|c|c|c|c|c|}
\hline \multirow{2}{*}{$\begin{array}{l}\text { Atom } \\
\text { No. }\end{array}$} & \multicolumn{2}{|c|}{$\mathrm{XDE}$} & \multicolumn{2}{|c|}{ NK372135A } \\
\hline & $\delta_{\mathrm{C}}(\mathrm{m})$ & $\delta_{\mathrm{H}}(\mathrm{m}, J \mathrm{~Hz})$ & $\delta_{\mathrm{C}}(\mathrm{m})$ & $\delta_{\mathrm{H}}(\mathrm{m}, J \mathrm{~Hz})$ \\
\hline 1 & $173.30(\mathrm{~s}, 2 \mathrm{C})$ & & $172.98(\mathrm{~s})$ & \\
\hline $\mathrm{I}^{\prime}$ & & & 159.78 (brs) & \\
\hline 2 & 116.18 (brs, 2C) & & 117.74 (brs) & \\
\hline $2^{\prime}$ & & & $61.14(\mathrm{brd})$ & $4.76(t, 7.3)$ \\
\hline 3 & $127.46(\mathrm{~d}, 2 \mathrm{C})$ & $7.01(\mathrm{~s}, 2 \mathrm{H})$ & $131.92(\mathrm{~d})$ & $6.50(\mathrm{~s})$ \\
\hline $3^{\prime}$ & & & $40.33(t)$ & $\begin{array}{l}3.13(\mathrm{dd}, 7.3,13.6) \\
3.19(\mathrm{dd}, 7.3,13.6)\end{array}$ \\
\hline 4 & $124.83(\mathrm{~s}, 2 \mathrm{C})$ & & $128.19(\mathrm{~s})$ & \\
\hline $4^{\prime}$ & & & $125.73(\mathrm{~s})$ & \\
\hline 5,9 & $131.74(\mathrm{~d}, 4 \mathrm{C})$ & $7.78(\mathrm{~d}, 8.8,4 \mathrm{H})$ & $132.26(\mathrm{~d}, 2 \mathrm{C})$ & $7.61(\mathrm{~d}, 8.8,2 \mathrm{H})$ \\
\hline $5^{\prime}, 9^{\prime}$ & & & $131.60(\mathrm{~d}, 2 \mathrm{C})$ & $7.21(\mathrm{~d}, 8.8,2 \mathrm{H})$ \\
\hline 6,8 & $114.47(\mathrm{~d}, 4 \mathrm{C})$ & $6.98(\mathrm{~d}, 8.8,4 \mathrm{H})$ & $115.33(\mathrm{~d}, 2 \mathrm{C})$ & $6.97(\mathrm{~d}, 8.8,2 \mathrm{H})$ \\
\hline $6^{\prime}, 8^{\prime}$ & & & $115.12(\mathrm{~d}, 2 \mathrm{C})$ & $6.86(\mathrm{~d}, 8.8,2 \mathrm{H})$ \\
\hline 7 & $161.14(\mathrm{~s}, 2 \mathrm{C})$ & & $162.69(\mathrm{~s})$ & \\
\hline $7^{\prime}$ & & & $160.69(s)$ & \\
\hline 10 & $55.43(\mathrm{q}, 2 \mathrm{C})$ & $3.87(\mathrm{~s}, 6 \mathrm{H})$ & $55.94(q)$ & $3.83(\mathrm{~s}, 3 \mathrm{H})$ \\
\hline $10^{\prime}$ & & & $55.71(q)$ & $3.75(\mathrm{~s}, 3 \mathrm{H})$ \\
\hline
\end{tabular}

a Recorded in $\mathrm{CDCl}_{3}$.

b Refered to Fig. 1.

supported by two proton couplings at $\mathrm{H}_{2}, v s .2 \mathrm{H}_{3}$, $[J=7.3]$ and $\mathrm{H}_{3},(\delta 3.13)$ vs. $\mathrm{H}_{3},(\delta 3.19)[J=13.6]$ and long range couplings at $\mathrm{H}_{2}, v, \mathrm{H}_{3}$ and at $\mathrm{H}_{3}$, vs. $\mathrm{H}_{5^{\prime}}, \mathrm{H}_{9^{\prime}}$ (Data not shown ). However, it was not clear whether $\mathrm{C}_{1},\left(\delta_{\mathrm{C}}\right.$ 159.78) was attributed to isonitril $\left(-\mathrm{N} \equiv \mathrm{C}_{1}\right)$ or nitril $\left(-\mathrm{C}_{1} \equiv \mathrm{N}\right)$ group. According to HMBC NMR analysis a signal at $\mathrm{C}_{1}$. $\left(\delta_{\mathrm{C}} 159.78\right) v s . \mathrm{H}_{3},\left(\delta_{\mathrm{H}} 3.13,3.19\right)$ was not observed. Therefore, isonitril group was reasonable as shown in Fig. 1.

NK $372135 \mathrm{~B}$ and $\mathrm{C}$ were considered to be in the same fundamental structure, since NMR spectrometric data of $\mathrm{C}_{1^{\prime}}, \mathrm{C}_{2^{\prime}}, \mathrm{C}_{3^{\prime}}$, carbons, $\mathrm{H}_{2^{\prime}}, \mathrm{H}_{3^{\prime}}$, protons and IR spectrum on isonitril groups (around 2102 and 2137) were quite identical. In comparison with the data of NK372135A, B and C lost a signal of $\mathrm{H}_{8}$, suggesting a substitution had occured. In NK372135B there were additional signals of $\delta_{\mathrm{C}} 55.9[\mathrm{q}]$ and $\delta_{\mathrm{H}} 3.29[\mathrm{~s}, 3 \mathrm{H}]$ and a chemical shift of $\mathrm{C}_{8}$ altered to $148.95 \mathrm{ppm}$. Therefore it was concluded that a $\mathrm{H}_{8}$ proton was substituted with $-\mathrm{OCH}_{3}$ group (Fig. 1). In NK372135C an additional signal of proton was detected at $\delta_{\mathrm{H}} 5.63$ $(\mathrm{s}, 1 \mathrm{H})$ and chemical shift of $\mathrm{C}_{8}$ altered to $145.68 \mathrm{ppm}$. Therefore it was concluded that $\mathrm{H}_{8}$ proton was substituted with $-\mathrm{OH}$ group (Fig. 1). These structural elucidations on the NK372135s were consistent with the data of molecular formula deduced.

The growth inhibition activity of NK372135s and
Table 2. Anti-Candida albicans activity of NK3721325s.

\begin{tabular}{lc}
\hline Compound & $\mathrm{IC}_{50}(\mu \mathrm{g} / \mathrm{ml})^{\mathrm{a}}$ \\
\hline Nystatin & 0.8 \\
NK372135A & 2.12 \\
NK372135B & 0.53 \\
NK372135C & 0.27 \\
XDE & 12.1 \\
XTE & 8.2 \\
\hline
\end{tabular}

a $\mathrm{IC}_{50}$ value was determined with micro-liquid dilution method. Candida albicans strain was inoculated in a buillon medium (Meat extract $1 \%$, Peptone $1 \%$ and $\mathrm{NaCl} 0.5 \%[\mathrm{pH}=7.2]$ ) and cultured at $30^{\circ} \mathrm{C}$ for 16 hours. The growth was monitored by $\mathrm{OD}_{600}$ and $\mathrm{IC}_{50}$ value was estimated.

xanthocillins against Candida albicans was examined. As shown in Table 2 NK372135A had stronger activity than XDE. Similarly NK372135B was stronger than methoxy-xanthocillin $\mathrm{X}$ dimethylether $(\mathrm{XTE})^{2)}$ which was dehydrogenated at $\mathrm{C}_{2}-\mathrm{C}_{3}$ bond of NK372135B (Fig 1). These results suggested that the hydrogenated structrue of NK372135 at $\mathrm{C}_{2}-\mathrm{C}_{3}$ bond must be needed for high anti-Candida activity. Among NK372135s the substitution of $\mathrm{H}_{8}$ also affected the anti-Candida activity of NK372135 (Table 2) and NK372135C showed the most potent activity against Candida albicans. Our preliminary data showed that NK372135s had an activity against other clinically troublesome fungus, i.e. Crypto coccus neoformans and so on. The precise biological 
properties and antifungal activity in vivo are now under the examination and will be reported elsewhere.

\section{Acknowledgments}

We would like to thank to Dr. HiRoshi Naganawa, Institite of Microbial Chemistry for measurement of HMBC NMR spectrum and Dr. AKIRA Takatuki, Riken Institute for kind gift of Xanthocillin derivatives and $\mathrm{Mr}$. SHINYA SATo, Nippon Kayaku Co., Ltd., for his technical assistance.

\section{References}

1) HAGEDORN, I. \& H. TONJES: Konstitutionsaufklarung von Xanthocillin, einem neuen Antibiotikum Pharmazie 12: $567 \sim 580,1957$

2) Takatuki, A.; S. Suzuki, K. Ando, G. Tamura \& K. ARIMA: New antiviral antibiotics; Xanthocillin $X$ mono-, and dimethylether and methoxy-xanthocillin $\mathrm{X}$ dimethylether. I. Isolation and characterization J. Antibiotics 21: $671 \sim 675,1968$ 